\title{
Mangrove growth dynamics and sediment relations in South Western Nigeria
}

\author{
Dinamika pertumbuhan mangrove dan hubungan sedimen di Nigeria Barat Selatan
}

Ufuoma Efe Akpovwovwo $^{\text {a }}$

${ }^{a}$ Department of Geography and Regional Planning, Delta State University, Abraka, Delta State, 330106, Nigeria [+234 8028364196]

\section{Article Info:}

Received: 05 - 06 - 2020

Accepted: 28 - 12 - 2020

\section{Keywords:}

Mangroves, Sediment, Structure, Nigeria

Corresponding Author: Ufuoma Efe Akpovwovwo Department of Geography and Regional Planning, Delta State University;

Tel. +2348028364196

Email:

akpovwovwo@delsu.edu.ng

\begin{abstract}
The mangrove ecosystem is not exempted from the fundamental interlinkages of components ensuring their functionality and development. Proper understanding of the interrelations between sediment parameters and their potential influence on mangrove growth is limited. This study examined mangrove structure across south western Nigeria, their growth dynamics, successional stage and relationship with the underlying sediments. Vegetation measurements and soil sampling $(0-30 \mathrm{~cm})$ were carried out in one hundred quadrats of $20 \mathrm{~m}$ by $20 \mathrm{~m}$. Sediments underwent laboratory analysis using standard procedures. Multiple regression was used to evaluate the relationship between the sediments and structural parameters at the 0.05 significance level. Ongoing degradation was detected, with evidence of selective harvesting targeted in the critical younger classes of $<6 \mathrm{~cm}, 6.1-9 \mathrm{~cm}$ and 9.1-13 cm. Phosphorus, magnesium, pH, salinity, sodium, silt and organic carbon were significant factors, contributing approximately 53 percent to the height. Electrical conductivity, organic carbon, salinity, total acidity, $\mathrm{pH}$ and silt were significant factors, contributing approximately 56 percent to the girth. The mangrove forests, though at a matured stage, are endangered. Sediment parameters, especially texture, have a significant influence on mangrove growth. Preparation of specialized sediment treatments for mangrove regrowth sites and also the setting up of conservation sites should be adopted.
\end{abstract}

How to cite (CSE Style $8^{\text {th }}$ Edition):

Akpovwovwo UE. 2020. Mangrove growth dynamics and sediment relations in South Western Nigeria. JPSL 10(4): 688-698. http://dx.doi.org/10.29244/jpsl.10.4.688-698.

\section{PRELIMINARY}

Mangroves form a major part of wetlands in various places, especially in the tropics. They are adapted to brackish water, having unique feeding links and associated interactions with a myriad of other organisms (Macnae, 1968; Lugo and Snedaker, 1974; Tomlinson, 1986). They are usually found growing as belts parallel to the coast lines. According to Kusmana and Sukristijiono (2016), Mangroves are forests, adapted to habitats characterized by high salinity conditions and flooding conditions dependent on tide variation. Globally, approximately $75 \%$ of tropical coastlines receiving freshwater drainage, play host to the mangrove ecosystem (Wang et al., 2003). Valiela et al., (2001) notes that the largest proportions of mangroves occur within the continents of Asia and the Americas. Nations of the world can be ranked in increasing order of importance based on the mangrove coverage, ranging from Indonesia to Australia. The areal coverage of mangroves 
scattered all over the world include the following: Indonesia $\left(4.25 \times 10^{4} \mathrm{~km}^{2}\right)$ (Spalding et al., 1997), Brazil $\left(1.34 \times 10^{4} \mathrm{~km}^{2}\right)$ (Spalding et al., 1997), Nigeria $\left(1.05 \times 10^{4} \mathrm{~km}^{2}\right)$ (Saenger and Bellan, 1995) and Australia $\left(1.00 \times 10^{4} \mathrm{~km}^{2}\right)$ (Robertson and Duke, 1990). According to FAO (2007), about 15.2 million hectares of mangroves are estimated to exist worldwide as at 2005, down from 18.8 million hectares in 1980. Five countries (Indonesia, Australia, Brazil, Nigeria and Mexico) together account for about $48 \%$ of the total global area and $65 \%$ of the total mangrove area is found in just ten countries. The remaining $35 \%$ is spread over 114 countries and areas, of which 60 have less than 10000 ha of mangroves each. Nigeria has the third largest expanse of mangrove in the world. The most common species, Rhizophora racemosa occurs along the shoreline, while Rhizophora harrisonii occurs majorly midzone and Rhizophora mangle towards the hinterland. Other species are found in stunted and shrub forms, such as Avicennia africana, A. nitida and Laguncularia racemosa. Conocarpus erectus and other woody species are usually found associated with mangroves, occurring especially at the edge, usually close to the sea (FAO, 1994).

The fact that environmental degradation is now a global phenomenon can not be overemphasized. Pribadi and Kartiasih (2020) noted that the drivers of degradation in any environment were population explosion and poverty. Coastal environments, which play host to mangrove forests, are not exempted. Against the background of ongoing global population explosion, coastal lands function as available land in the prevailing situation of land scarcity. This is in addition to the fact that it is a major base for oil exploration and exploitation activities, and are hence under intense pressure. These coastal lands, and by consequence, mangrove forests, being fragile also bear the repercussion of climate change culminating ultimately in coastal erosion. In recent times, a number of interventions set up to ensure protection and management, have however proven to be unsustainable. Several of the studies, focused on producing solutions, are usually on a localized basis, leaving much to be expected. Further corroborating this, James et al. (2007) noted there has been no large-scale study cutting across a major part of the Niger Delta as a whole. A proper understanding of the drivers of mangrove growth across large sections of the Niger Delta should be attained. It is expected that a comparison of both localized and large regions will elicit a proper understanding of intricacies of mangrove growth and dynamics, for the purpose of management and planning. In addition, a comprehension of the inherent relationships especially regarding the underlying sediments. An understanding of the inherent relationships with the underlying sediment is critical. It has been shown in a number of studies that underlying sediments are a major driver of growth within the mangrove environment (D1 'az and Blackburn, 2003); Green et al. (1997), Conti et al. (2016). This paper therefore examined mangrove structure and growth pattern and their underlying sediments in the south western portion of the Niger Delta. The paper set out to test the relationship between mangrove forest structure and the sediment characteristics.

\section{METHOD}

\section{Research Location}

The study area is located in the South Western part of Nigeria, and lies approximately between latitudes $5^{\circ} 00^{\prime} 00^{\prime \prime}$ and $6^{\circ} 00^{\prime} 00^{\prime} \mathrm{N}$ and longitudes $5^{\circ} 00^{\prime} 00^{\prime \prime}$ and $6^{\circ} 00^{\prime} 00^{\prime \prime} \mathrm{E}$ (Figure 1). For the purpose of holistic representation, the study sites were located within the creeks of four major rivers adjoining the coast: Agge (Ramos River), Burutu (Forcados River), Opuama (Benin River) and Kurutie (Escravos River). The control site was located in Falcorp mangrove conservation site in Ifie. The study area is characterized by the Tropical Equatorial Climate (Iloeje, 1981). The study area is characterized by mean annual temperatures of $31^{\circ} \mathrm{C}$ all year round and a mean relative humidity of $83 \%$ (Efe, 2007). The geology of the study area consists mainly of sedimentary rock formations (Short and Staeuble, 1967). 

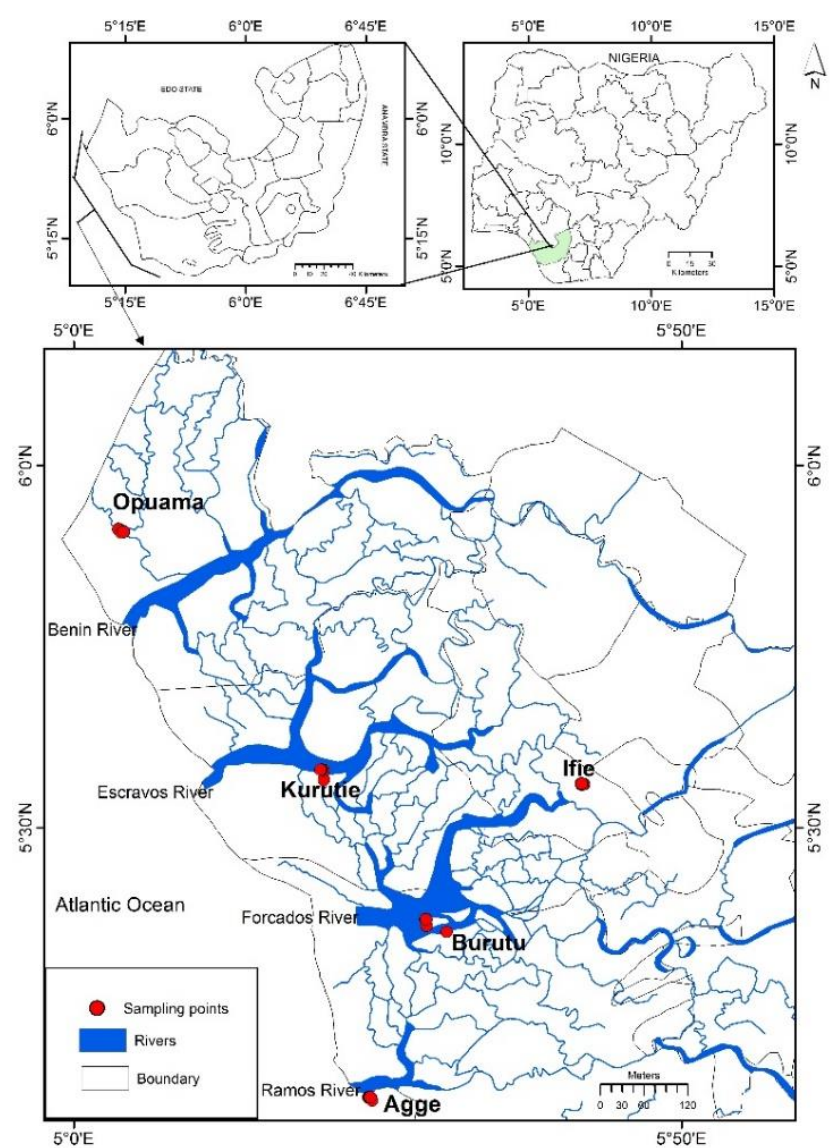

Figure 1 Map of Delta state showing the study area

\section{Method of collecting Data}

The research method adopted is both exploratory and causal. Vegetation measurements and sediment samples were taken from a total of one hundred quadrats. Measurements were taken from twenty quadrats each from the four sites and the control. These quadrats of $20 \mathrm{~m}$ by $20 \mathrm{~m}$ each, were located within the creeks surrounding each of the four major rivers linking the hinterland with the Atlantic Ocean. These rivers include the following: Benin River, Forcados River, Escravos River, and Ramos River. Within each quadrat, vegetation measurements (Girth, diameter at breast height, basal area, height, crown diameter, tree density) and sediment sampling were carried out. Sediment sampling was carried out using a sediment core. One sediment sample each, taken from each quadrat at a depth of 0 until $30 \mathrm{~cm}$, were collected from the sample and control sites. The sediment samples were collected in well labelled bags.

\section{Data Analysis Method}

The sediment samples underwent laboratory analysis (according to standard procedures which have been published) for the following parameters: Particle size composition (Hydrometer method, Bouyoucos, 1951), Soil pH, Electrical Conductivity, Organic carbon (Walkey Black combustion method), Total Nitrogen (Kjeldahl method), Phosphorus (Bray-P1 method), Exchangeable cations (Calcium, Sodium, Potassium and Magnesium) flame photometer and atomic absorption spectrophotometer, Exchangeable acidity, Cation Exchangeable Capacity (Summation method), Total Nitrogen (Kjeldahl method). Quantitative research methods were applied to the data in the form of Multiple Regression (causality analysis). Multiple regression was used to test the cause - effect relationship between the mangrove structure (Height and Girth) and sediment parameters. 


\section{RESULTS AND DISCUSSION}

The highest means for the DBH $(32.46 \mathrm{~cm})$, Basal Area $(0.1 \mathrm{msq} / \mathrm{ha})$ and height $(21.72 \mathrm{~m})$ were observed in Kurutie. These mean values were closely followed by those in Agge (in order of magnitude), in addition to having the highest mean crown diameter $(8.22 \mathrm{~cm})$ and tree density $(448.8 \mathrm{t} / \mathrm{Ha})$ (Tabel 1). The highest mean tree density was observed in the control, with all the other parameters being the lowest. This was closely followed by the mangroves in Agge (449 trees/Ha) while the lowest occurred in Kurutie (282.55 t/Ha). The mean structural values for the study sites together, were much higher than the mean values in the control site (Figure 2-6).

Table 1 Mean, min, max, and standard deviation values of dbh, height, basal area, and crown diameter of each location

\begin{tabular}{lcccc}
\hline \multicolumn{1}{c}{ Location } & Mean & Min & Max & SD \\
\hline DBH (cm) & & & & \\
\hline Agge (Ramos River) & 24.85 & 6.4 & 79.6 & 0.82 \\
Burutu (Forcados River & 18.39 & 6.37 & 82.8 & 0.74 \\
Opuama (Benin River) & 21.64 & 6.37 & 222.93 & 1.06 \\
Kurutie (Escravos River). & 32.46 & 6.37 & 208 & 0.96 \\
Control site & 14.33 & 3.18 & 277.07 & 0.57 \\
\hline Height (m) & & & & \\
\hline Agge (Ramos River) & 18.0 & 1.3 & 49.7 & 0.61 \\
Burutu (Forcados River & 12.57 & 2 & 48.6 & 0.51 \\
Opuama (Benin River) & 16.35 & 0.6 & 47.1 & 0.85 \\
Kurutie (Escravos River). & 21.72 & 2.9 & 35.7 & 0.71 \\
Control site & 11.22 & 0.94 & 74.4 & 0.16 \\
\hline Basal area (m²/ha) & & & & \\
\hline Agge (Ramos River) & 0.07 & 0.01 & 0.5 & 0.01 \\
Burutu (Forcados River & 0.04 & 0.01 & 0.54 & 0.00 \\
Opuama (Benin River) & 0.06 & 0.01 & 3.93 & 0.02 \\
Kurutie (Escravos River). & 0.10 & 0.01 & 1.54 & 0.01 \\
Control site & 0.04 & 0.01 & 6.03 & 0.01 \\
\hline Crown diameter (m) & & & & \\
\hline Agge (Ramos River) & 8.22 & 2 & 27 & 0.25 \\
Burutu (Forcados River & 6.45 & 0.4 & 26 & 0.26 \\
Opuama (Benin River) & 7.91 & 1.6 & 17 & 0.39 \\
Kurutie (Escravos River). & 7.63 & 1 & 21.5 & 0.27 \\
Control site & 4.56 & 0.2 & 13.2 & 0.06 \\
\hline Tree density (tree /ha) & & & & \\
\hline Agge (Ramos River) & 448.8 & 225 & 625 & 20.95 \\
Burutu (Forcados River & 351.2 & 200 & 775 & 27.98 \\
Opuama (Benin River) & 315 & 225 & 500 & 16.06 \\
Kurutie (Escravos River). & 585.625 & 375 & 775 & 15.9 \\
Control site & & & 475.58 \\
\hline & & & & \\
\hline & & & & \\
\hline
\end{tabular}




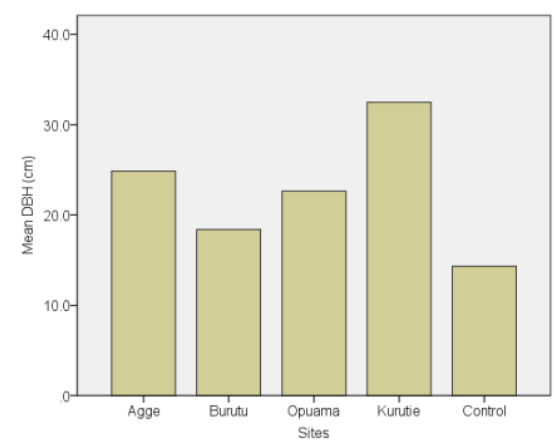

Figure 2 Mean DBH for each site

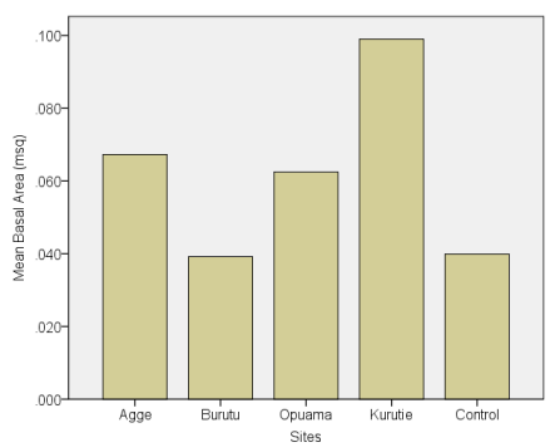

Figure 3 Mean basal area for each site

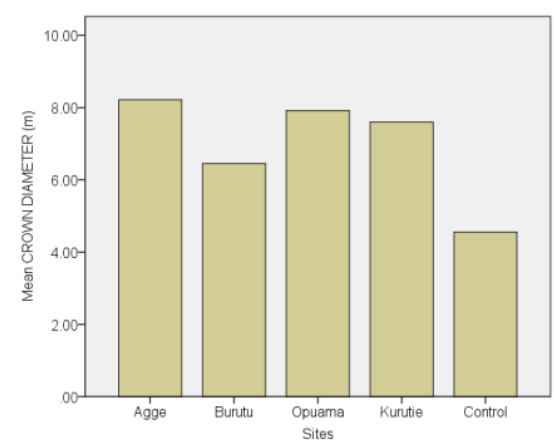

Figure 4 Mean crown diameter for each site

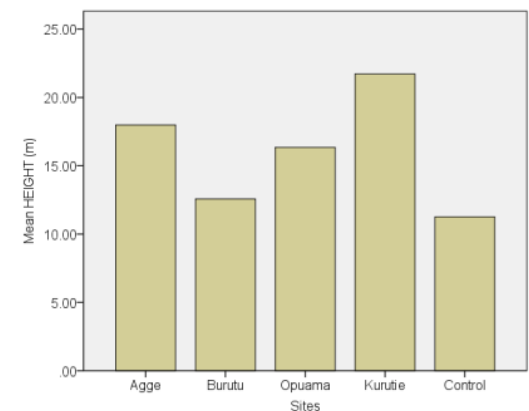

Figure 5 Mean height for each site

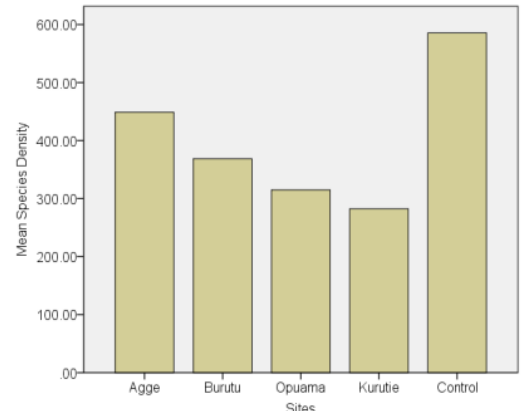

Figure 6 Mean tree density for each site

The designation of the class intervals was adapted from Mohammed et al. (2009). Figure 7 shows that there is a complete absence of mangroves in the $<6 \mathrm{~cm}$ diameter class. Very low values signifying low abundances are recorded in the 6.1 until $9 \mathrm{~cm}$ diameter class, after which there is a rise in the next diameter class of 9.1 until $13 \mathrm{~cm}$. In the study sites, mangrove abundance attains a peak either at the 9.1 until $13 \mathrm{~cm}$ or 13.1 until $20 \mathrm{~cm}$ class. This, however declines slightly in the older classes. Kurutie is however an exception as its peak abundance is recorded in the oldest class.

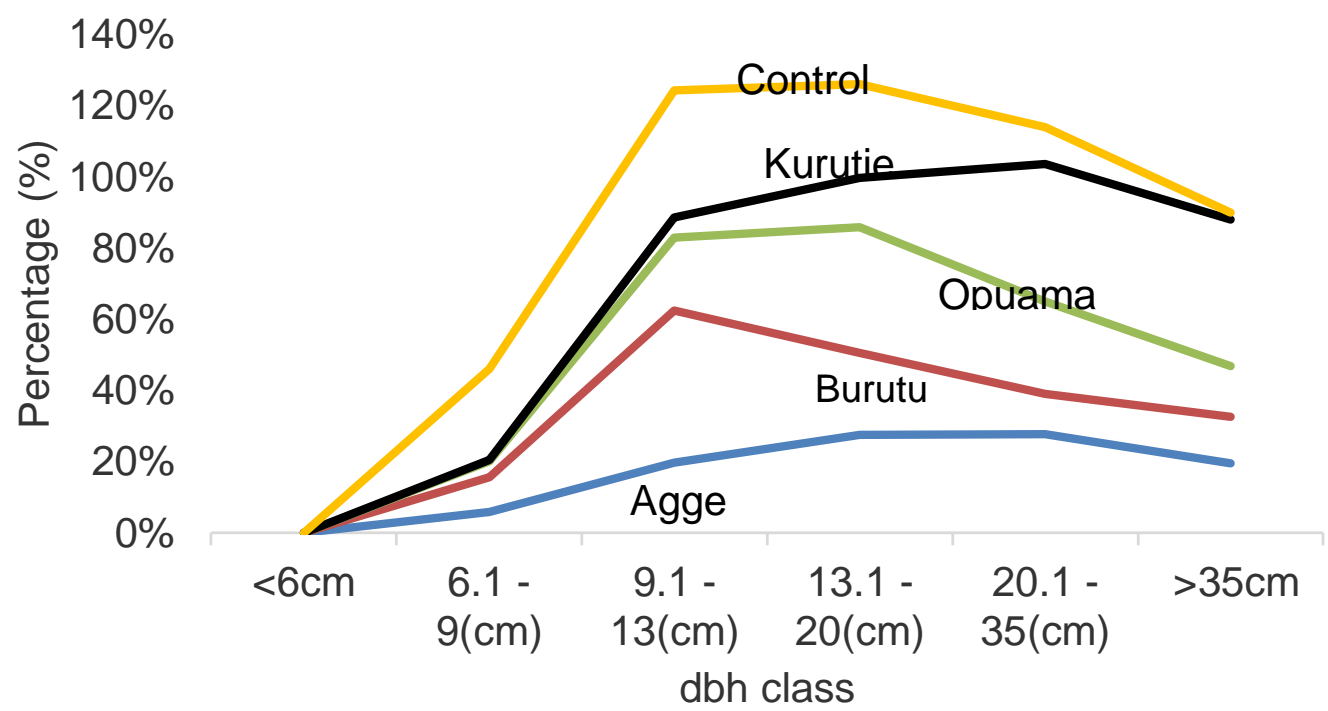

Figure 7 Mangrove abundance in the different dbh classes 
The sediment texture based on the mean particle composition percentages, revealed that the sediments of the sites fall into the sandy clay loam texture with the exception of Agge which falls into the clay textural class. Percentages of the various particle sizes varied slightly among the locations (Fig 7). The major variation was observed in Agge having the lowest mean sand percentage of approximately 27 percent which was outside the range of about 46 until 51 percent for the other locations. Kurutie soils, however had the highest mean value of approximately 52 percent for sand. The silt content for all the sites had a range of between 19 percent and 31 percent, with Agge having the highest mean silt content (31\%). Kurutie, however, had the lowest of mean silt percentage (19\%). The mean clay content percentage for the locations ranged between approximately 25 percent and 42 percent, with the control having the lowest clay content and Agge having the highest clay content. Kurutie has the lowest clay content for all the sites, having a content of 29 percent. The mean bulk densities ranged between $0.71 \mathrm{~g} / \mathrm{cm}^{3}$ in Kurutie to $1.09 \mathrm{~g} / \mathrm{cm}^{3}$, in Opuama. The mean bulk density value for the control was not much different from that of the sites, having a value of $0.82 \mathrm{~g} / \mathrm{cm}^{3}$. There seemed not to be much difference in the bulk density mean values, since the range between the values is rather small.

The $\mathrm{pH}$ values reveal that the sediments of study sites and the control are generally acidic, with values ranging between 3 and 4, with the exception of Opuama. Macintosh and Ashton (2003) noted that the soils of mangrove swamps in Nigeria are characterized by high acidity. The variation in $\mathrm{pH}$ could be attributed to tidal dynamics, proximity to ocean or nature of upstream activities. According to UNEP-WCMC (2007), operations of oil companies upstream, pertaining especially to the inefficient handling of dredging activity and resultant spoil, results in acidification and water contamination. In addition, Ejoh et al. (2018) noted that Nigerian rivers were generally acidic. The interaction and effect, therefore, of these rivers on the underlying sediments cannot be overemphasized. The organic carbon content in the control was highest (17.41\%) of all the sites, being attributable to its status as a conservation site. Hossain and Nurrudeen (2016), noted that soils with an organic carbon content higher than $10 \%$, were considered to be peaty in nature. The sediments in the other sites were an exception to this classification. This implies therefore that the sediments in the control can be classified as peaty, with the potential as a source of fuel and most importantly as a carbon store. Zamprogno et al. (2016) observed that Rhizophora soils have been observed to have relatively higher organic carbon content owing to the highly fibrous nature of its roots, in combination with its high generation of organic matter emanating from decaying litter. This is also the case with the control site sediments as they are composed solely of Rhizophora $s p$. The mean nitrogen content for all the sites was 0.67 percent while that of the control was 0.69 percent. The mean nitrogen content ranged between 0.54 percent (Burutu) to 0.89 percent (Agge). Salinity content was highest in Agge (232.40 g/liter) and the lowest occurring in Burutu ( $44.11 \mathrm{~g} /$ liter). The salinity content of the control was a little higher than that of Burutu (47.11g/liter). The highest salinity content recorded in Agge could likely be due to its relative proximity to the Atlantic Ocean, in contrast with the other sites. Consistent tidal inundation and flooding, as a result of its proximity are likely factors influencing salinity. The highest electrical conductivity value $(0.69 \mu \mathrm{s} / \mathrm{cm})$ was observed in the control, while the lowest occurred in Kurutie and Opuama $(0.56 \mu \mathrm{s} / \mathrm{cm})$. The highest total acidity content $(6.31 \mathrm{cmol} / \mathrm{kg})$ was observed in the Control, while Agge, had the lowest value of $1.66 \mathrm{cmol} / \mathrm{kg}$. Kurutie, however, had the highest value of $2.97 \mathrm{cmol} / \mathrm{kg}$, among all the study sites.

The phosphorus content was highest in Kurutie $(25.62 \mathrm{ppm})$, while the lowest was observed in Burutu (4.87 ppm). The highest mean sodium content was observed in Kurutie $(36.92 \mathrm{cmol} / \mathrm{kg})$ while the control had the lowest $(1.10 \mathrm{cmol} / \mathrm{kg})$. The potassium content was highest in Agge $(12.06 \mathrm{cmol} / \mathrm{kg})$ and lowest in the control. The same pattern is also recorded for the calcium mean values, with the sediments in Agge having the highest and Burutu, the lowest. The control also has the lowest overall magnesium value of $4.21 \mathrm{cmol} / \mathrm{kg}$. The highest magnesium content is recorded in Opuama $(1.89 \mathrm{cmol} / \mathrm{kg})$, while the lowest is observed in Burutu $(1.20 \mathrm{cmol} / \mathrm{kg})$. In general, the sediments in the control are observed to have the lowest overall values for all the exchangeable cations. This may likely be due to the control being located relatively more hinterland than the other sites, thereby resulting in the easy movement of nutrients downstream. Tidal inundation and flood waters usually serve as vehicles for the transportation of nutrients within mangrove ecosystems (Lugo and 
Snedaker, 1974; Davis et al., 2003; Reef et al., 2010). The mean values, however ranged between 18.94 to $36.92,11.46$ to $12.06,1.20$ to 1.48 and 17.23 to $46.30 \mathrm{cmol} / \mathrm{kg}$ for Sodium, Potassium, Magnesium and Calcium respectively. Agge recorded the highest ECEC $(87.48 \mathrm{cmol} / \mathrm{kg})$, while the lowest was observed in Burutu (51.33 cmol/kg). Deenik et al., (2005) classified CEC values of 80 until $120 \mathrm{cmol} / \mathrm{kg}$ as high, with the implication of the mean Effective Cation Exchangeable Capacity (ECEC) values for the experimental sites being categorised as high. The mean ECEC value for the control, is however, extremely lower than those of the other sites. The situation of high amounts of organic carbon being suggestive of higher potential for storage of ECEC, as alluded to by Hossain and Nurudeen (2016), however was not the case in this study. The reason being that despite the relatively high ECEC values in this study, the organic carbon content values were generally low. The sediment parameter means for all the sites together were higher than those for the control, with the exception of sand, silt, organic carbon, nitrogen and total acidity. Several studies have however observed mangrove sediment parameters to be highly variable especially in terms of nutrient content and sediment properties. This situation is not unconnected with the relatively low phylogenetic association among mangroves (Reef et al., 2010; Hossain and Nurudeen, 2016).

Multiple regression statistical analysis was used to test the relationship between the mangrove structure and the sediment characteristics at the 0.05 significance level. The height and girth, being representative of mangrove structure, were the dependent variables, while the sediment parameters were the independent variables. Phosphorus, magnesium, $\mathrm{pH}$, salinity, sodium, silt and organic carbon were significant, contributing approximately $53 \%$ to the height. Electrical conductivity, salinity, organic carbon, total acidity, $\mathrm{pH}$ and silt were significant, contributing approximately $56 \%$ of girth (Table 3). $\mathrm{pH}$, silt and salinity were common predictors to mangrove structure. Magnesium, organic carbon and electric conductivity were all negatively related and hence are limitations to mangrove structure and development (Table 2 and 3). The results also reveal that mangrove structure is influenced positively more by the physical parameters $(\mathrm{pH}$, silt, electrical conductivity) of the sediments and less by their nutrient contents.

Table 2 Summary of regression model for height and sediment characteristics in the study sites

\begin{tabular}{|c|c|c|c|c|c|}
\hline & $\begin{array}{c}\text { Sig. } \\
(P \text { Value })\end{array}$ & $R$ square & $B$ & Constant & Predictors \\
\hline Agge & 0.922 & 0.464 & $*$ & $*$ & $*$ \\
\hline Burutu & 0.005 & 0.369 & -10.051 & 25.137 & Magnesium \\
\hline Opuama & 0.881 & 0.565 & $*$ & $*$ & $*$ \\
\hline Kurutie & 0.028 & 0.242 & 40.296 & -463.740 & Potassium \\
\hline & $\begin{array}{l}0.008 \\
0.000 \\
0.000\end{array}$ & & $\begin{array}{c}0.077 \\
-4.305 \\
2.159\end{array}$ & & $\begin{array}{c}\text { Phosphorus } \\
\text { Magnesium } \\
\text { pH }\end{array}$ \\
\hline All study sites & $\begin{array}{l}0.001 \\
0.032 \\
0.001 \\
0.038\end{array}$ & 0.527 & $\begin{array}{c}0.019 \\
0.078 \\
0.107 \\
-0.428\end{array}$ & 7.002 & $\begin{array}{c}\text { Salinity } \\
\text { Sodium } \\
\text { Silt } \\
\text { OC }\end{array}$ \\
\hline Control & 0.652 & 0.338 & $*$ & $*$ & $*$ \\
\hline
\end{tabular}


Table 3 Regression model summary for girth and sediment

\begin{tabular}{|c|c|c|c|c|c|}
\hline $\begin{array}{c}\text { Location of the } \\
\text { Test }\end{array}$ & Sig & $R$ square & $B$ & Constant & Predictors \\
\hline Agge & 0.906 & 0.481 & $*$ & $*$ & $*$ \\
\hline Burutu & $\begin{array}{l}0.001 \\
0.004\end{array}$ & 0.625 & $\begin{array}{l}-47.684 \\
-4.534\end{array}$ & 140.645 & $\begin{array}{l}\text { Magnesium } \\
\text { Phosphorus }\end{array}$ \\
\hline Opuama & 0.226 & 0.850 & $*$ & $*$ & $*$ \\
\hline Kurutie & 0.600 & 0.776 & $*$ & $*$ & $*$ \\
\hline \multirow{6}{*}{ All study sites } & 0.000 & \multirow{6}{*}{0.558} & -0.162 & \multirow{6}{*}{32.557} & EC \\
\hline & 0.000 & & 0.250 & & Salinity \\
\hline & 0.000 & & -4.959 & & $\mathrm{OC}$ \\
\hline & 0.000 & & 4.431 & & Total Acidity \\
\hline & 0.007 & & 7.210 & & $\mathrm{pH}$ \\
\hline & 0.020 & & 0.533 & & Silt \\
\hline Control & 0.326 & 0.432 & $*$ & $*$ & $*$ \\
\hline
\end{tabular}

The relatively highest tree density observed in Agge is suggestive of the active occurrence and potential for growth, in spite of its sediments having the highest salinity content. Several studies have established the fact of salinity being a major constraint to mangrove growth. In view of this, it has been established that mangroves thrive better further inland, with minimal influx of salt water. Naidoo (1987), Kathiresan (1996), Lin and Sternberg (1993) and Suwa et al. (2009), for instance, noted that higher salinities adversely affect all aspects of the functioning, biomass accumulation and structural progression of mangroves. Remarkably, the contrary is the case in Agge, as the aforementioned tree density values reflect the thriving of the mangroves. Interestingly, Burutu was observed to have the lowest mean structural values, despite its proximity to the mainland. The situation in Burutu, however agrees with the status quo pertaining to the negative influence of salinity and mangrove survival, as depicted by its sediments having the lowest salinity content while also having the lowest tree density. These situations observed in the mangrove forests in Agge and Burutu, could be attributable to a combination of the presence of certain other unknown prevailing factors, which may be location specific. The tree density values are likely to be a function of the dominant mangrove species present. Sherman et al. (1998) noted that tree densities were usually higher in Rhizophora sp dominated mangrove forests. The scenario in Burutu and the control sites affirm this, as they are Rhizophora sp dominated and both rank highest in tree density values ( $775 \mathrm{t} / \mathrm{Ha}$ ). In a study by Kairo et al. (2002), the tree densities for Rhizophora sp ranged between $433 \mathrm{t} / \mathrm{Ha}$ and $545 \mathrm{t} / \mathrm{Ha}$, which is close to the $586 \mathrm{t} / \mathrm{Ha}$ observed in the Rhizophora sp dominated control site.

The generally low structural values and high tree density values in the control site is an indication of the relatively youthful character of the mangrove forest. This implies the occurrence of the ongoing process of regeneration, however, with the climax far from being attained. Further confirming this is the mean tree density value in the control site, being relatively higher than that for all the study sites. The complexity index in the control was also highest in the control site (8.14) and lowest in Burutu (1.98) (Table 2). According to Bosire et al. (2005) and Mohammed et al. (2009), complexity index is an indicator of overall structural development of a forest stand. This implies that the more complex a forest is, the more diverse structurally it should be. Structural development therefore suggests advancement in growth. The values in this study, however suggest the contrary. The control had the highest complexity index, in spite of its comparably highest mean tree density characterizing it as being in the youthful stage. The complexity indices of the study sites were relatively much lower. Evidence, however, of their older age status is depicted by their higher mean structural values. Tree density, as a factor of growth, can therefore be said to be critical. It should therefore, to be incorporated within the complexity index equation to ensure robustness and effective interpretation. 
The stem diameter is known to give an indication of the size of the trunk from which its probable age can be derived or inferred. Mean dbh generally increases with stand age and has been used to discriminate between successional stages in Douglas-fir forests (Spies and Franklin, 1991), hemlock-hardwood forests (Ziegler, 2000), McElhinny (2002). In other words, an examination of dbh values serves as a good basis for the assessment of the extent and nature of forest growth. The lowest abundances occurring in the younger dbh classes of $<6 \mathrm{~cm}$ and 6.1 to $9 \mathrm{~cm}$ is unexpected and is suggestive of the truncation of growth resulting in a trend of degradation or growth retardation. The absence observed in the youngest class $(<6 \mathrm{~cm})$ could be attributed to crab predation, species competition or other unknown location specific factors. The situation of low abundances observed in the $6.1-9 \mathrm{~cm}$ class could be linked to selective harvesting or other unknown factors which may be in close proximity. This underscores the issue of the influence of other factors within the immediate environment, otherwise characterized as location specific. The abundances in the different dbh classes vary, with a rise from the younger classes which climaxes within the 9.1 to $20 \mathrm{~cm}$ classes and the declines. The situation in Kurutie varies slightly, with a rise in abundances of the 20.1 to $35 \mathrm{~cm}$ class. A decline however occurs in the older class of $>35 \mathrm{~cm}$. The mangroves in Kurutie are, hence, characteristic of the old/mature stage of succession. The observed uneven nature of the abundances in the different dbh classes differs from the view of Mckee (2002) which notes that mangrove forests are usually even aged and usually composed of one strata. The situation in the control follows the same trend as that of the study sites however with a steep rise in the younger classes $(6$ to $13 \mathrm{~cm})$, characterized by relatively higher abundances. This is indicative of a young forest. This implies evidence of the potential for growth in spite of the ongoing trend of degradation. Evidence of the degradation trend is implied from the gap in mangrove abundances in the youngest class of $<6 \mathrm{~cm}$. Notwithstanding the similarity in trend, the abundances in the various dbh classes in the control are relatively higher than those of the study sites.

The percentage sediment parameter contribution of about 50 percent for both girth and height suggests the presence other unknown factors. Interestingly, salinity is positively related, implying that it is not a limitation to mangrove growth. This is a confirmation of the aforementioned situation of high salinity and high tree density occurring in Agge. Further corroborating this, salinity did not emerge as a significant contributor in any of the individual study sites. The situation in the control site was totally different, as none of the sediment parameters were predictors of both height and girth. This suggests that there are other important factors which might be location specific and/or are not sediment related. This may also be suggestive of the resultant effect of the certain prevailing factors culminating in the alteration of major aspects of the environment. Seedo et al. (2017) confirmed this by noting that an understanding of the functionality of location specific factors were as important as other already generally established factors. Some of which could be the fauna, tidal regime and other environmental conditions.

The study sites are at varying levels of succession while the control is at the youthful stage. There is evidence of degradation, due likely to selective harvesting targeted majorly at the younger dbh classes. The sediment parameters were discovered to be drivers of the development of girth and height, however with evidence of the operation of other non-sediment related factors which are likely to be location specific.

\section{CONCLUSION}

This study has shown that the mangrove forest in the western section of the Niger Delta is at a mature stage of succession, however undergoing degradation, especially through selective harvesting. The control site is much younger, but with potential for efficient growth. Salinity, as a limitation to mangrove growth and development, has been debunked in this study suggesting its likely collaboration with other location specific factors in its influential role in the mangrove ecosystem. The soil texture is pertinent to mangrove structural development, as depicted in silt being a dominant factor. The results in the control site suggest the need to further examine other aspects of the mangrove environment with the aim of discovering other contributory factors, for the purpose of replicating the growth and stability observed in the control site. The setting up of 
mangrove regrowth projects in degraded sites and the formulation of specialized soil treatments for the purpose of enhancing growth is recommended. In addition, more Ramsar and mangrove conservation sites should be established.

\section{REFERENCES}

[FAO] Food and Agricultural Organization. 1994. Mangrove Forest Management Guidelines. Rome (RO): FAO Forestry Paper.

[FAO] Food and Agricultural Organization. 2007. The State of Food and Agriculture. Rome (RO): FAO Agricultural series.

[UNEP-WCMC] United Nations Environment Programme-World Conservation Monitoring Centre. 2007. Mangroves of Western and Central Africa. Cambridge (GB): UNEP-WCMC.

Bosire JO, Kairo JG, Kazungu J, Koedan N, Dahdouh-Guebas F. 2005. Predation on propagules regulates regeneration in a high density reforested mangrove plantation. Marine Ecology. 299: 149-155.

Bouyoucos GJ. 1951. A recalibration of the hydrometer method for making mechanical analysis of soils. Agronomy Journal. 43: 435-438.

Conti LA, Sampaio de Arauja CA, Cunha-Lignon M. 2016. Spatial database modelling for mangrove forests mapping: Examples of two estuarine systems in Brazil. Model Earth Systems and Environment. 73(2): $1-12$.

Davis SE, Corronado-Molina C, Childers DL, Day JW. 2003. Temporally dependent C, N, and P dynamics associated with the decay of Rhizophora mangle L. leaf litter in oligotrophic mangrove wetlands of the Southern everglades. Aquat Bot. 75: 199-215.

Deenik J, Uchida J, Silva JA. 2005. Nitrogen dynamics in a flooded taro soil amended with fish/blood meal. In: Stevens WB, editor. Proceedings of the Western Region Nutrient Management Conference 6; 2005 March 3-4; Salt Lake City, Country. Salt Lake City (US): University of Hawai'i.

D1 'az BM, Blackburn GA. 2003. Remote sensing of mangrove biophysical properties: Evidence from a laboratory simulation of the possible effects of background variation on spectral vegetation indices. International Journal of Remote Sensing. 24: 53-73.

Efe SI. 2007. Climate of Delta State. Abraka (NG): Delta State University.

Ejoh AS, Unuakpa BA, Ibadin FH, Edeki SO. 2018. Dataset on the assessment of water quality and water quality index of Ubogo and Egini rivers, Udu LGA, Delta State Nigeria. Data in Brief. 19: 1716-1726.

Green EP, Mumby PJ, Edwards AJ, Clark CD, Ellis AC. 1997. Estimating leaf area index of mangroves from satellite data. Aquatic Botany. 58: 11-19.

Hossain MD, Nuruddin AA. 2016. Soil and mangrove: A review. Journal of Environmental Science and Technology. 9: 198-207.

Iloeje NP. 1981. A New Geography of Nigeria. Lagos (NG): Longman.

James GK, Adegoke JO, Saba E, Nwilo P, Akinyede J. 2007. Satellite-based assessment of the extent and changes in the mangrove ecosystem of the Niger Delta. Marine Geodesy. 30: 249-267.

Kairo JG, Dahdouh-Guebas F, Gwada PO, Ochieng C, Koedan N. 2002. Regeneration status of mangrove forests in Mida creek, Kenya: A compromised or secured future?. Ambio. 31: 7-8.

Kathiresan K, Rajendran N, Thangadurai G. 1996. Growth of mangrove seedlings in the intertidal area of Vellar estuary, southeast coast of India. Indian Journal of Marine Science. 25: 240-243.

Kusmana C, Sukristijiono. 2016. Mangrove resource uses by local community in Indonesia. Journal of Natural Resources and Environmental Management. 6(2): 217-224.

Lin G, Sternberg LSL. 1993. Effects of salinity fluctuation on photosynthetic gas exchange and plant growth of the red mangrove (Rhizophora mangle L.). Journal of Experimental Botany. 44: 9-16.

Lugo AE, Snedaker SC. 1974. The ecology of mangroves. Annual Review of Ecology and Systematics. 5: 3964. 
Macintosh DJ, Ashton EC. 2003. Report on the Africa Regional Workshop on The Sustainable Management of Mangrove Forest Ecosystems. Washington DC (US): World Bank.

Macnae W. 1968. A general account of the fauna and flora of the mangrove swamps and forests in the IndoWest-Pacific Region. Advances in Marine Biology. 6: 73-270.

McElhinny C. 2002. Forest and Woodland as an index for Biodiversity: Review. Canberra (AU): Australian National University.

McKee KL. 2002. Trophic structure and ecological significance. In: Feller IC, Sitnik M, editors. Mangrove Ecology: A Manual for a Field Course. Washington DC (US): Smithsonian Institution.

Mohammed MOS, Neukermans G, Kairo JG, Dahdouh-Guebas F, Koedam N. 2009. Mangrove forests in a peri-urban setting: The case of Mombasa (Kenya). Wetlands Ecology and Management. 17: 243-255.

Naidoo G. 1987. Effect of salinity and nitrogen on growth and water relations in the mangrove, Avicennia marina (Forsk.) Vierh. New Phytologist. 107: 317-325.

Pribadi W, Kartiasih F. 2020. Environmental quality and poverty in Indonesia. Journal of Natural Resources and Environmental Management. 10(1): 89-97. doi: http://dx.doi.org/10.29244/jpsl.10.1.89-97.

Reef R, Feller IC, Lovelock CE. 2010. Nutrition of mangroves. Tree Physiology. 30(9): 1148-1160.

Robertson AI, Duke NC. 1990. Mangrove fish-communities in tropical Queensland, Australia. Spatial and temporal patterns in densities, biomass and communities structure. Marine Biology. 104: 369-379.

Saenger P, Bellan MF. 1995. The Mangrove Vegetation of the Atlantic Coast of Africa. Toulouse (FR): University of Toulouse Press.

Seedo KA, Abido MS, Salih A, Abahussain A. 2017. Structure and composition of mangrove associations in Tubli bay of Bahrain as affected by municipal wastewater discharge and anthropogenic sedimentation. International Journal of Biogeography. 2017: 1-9. doi: https://doi.org/10.1155/2017/2084256.

Sherman RE, Fahey TJ, Howarth RW. 1998. Soil-plant interactions in a neotropical mangrove forest: Iron, phosphorus and sulfur dynamics. Oecologia. 115: 553-563.

Short KC, Stauble AJ. 1967. Outline of geology of Niger Delta. American Association of Petroleum Geologists Bulletin. 51: 761-779.

Spalding MD, Blasco F, Field CD. 1997. World Mangrove Atlas. Okinawa (JP): International Society for Mangrove Ecosystems.

Spies TA, Franklin JF. 1991. The structure of natural young, mature, and old-growth douglas-fir forests in Oregon and Washington. In: Aubry KB, Brookes MH, Agee JK, Anthony RG, Franklin JF, editors. Wildlife and Vegetation of Unmanaged Douglas-Fir Forests. Oregon (US): USDA Forest Service. p 91109.

Suwa R, Deshar R, Hagihara A. 2009. Forest structure of a subtropical mangrove along a river inferred from potential tree height and biomass. Aquatic Botany. 91: 99-104.

Tomlinson PB. 1986. The Botany of Mangroves. Cambridge (GB): Cambridge University Press.

Valiela I, Bowen JL, York JK. 2001. Mangrove forests: one of the world threatened major tropical environments. Bioscience. 51(10): 810-815.

Wang Y, Bonynge G, Nugranad J, Traber M, Ngusaru A, Tobey J, Hale L, Bowen R, Makota V. 2003. Remote sensing of mangrove change along the Tanzania Coast. Marine Geodesy. 26: 35-48.

Ziegler SS. 2000. A comparison of structural characteristics between oldgrowth and postfire second growth hemlock-hardwood forests in Adirondack Park, New York, USA. Global Ecology and Biogeography. 9: 373-389.

Zamprogno GC, Pereira-Tognella MMP, Quaresma VS, Pascoalini SS, Facco do Couto G. 2016. The structural heterogeneity of an urbanised forest area in South Eastern Brazil: Influence of environmental factors and the anthropogenic stressors. Brazilian Journal of Oceanography. 64(2): 157-172. 